\title{
Anal Fistula and Stem Cell
}

\section{Abdrabo Mashhour *}

Cairo University, Cairo, Egypt

*Corresponding author: Mashhour A, General Surgery Department, Cairo University, Cairo, Egypt, Tel: 02-2363-3302; E-mail: mashour24@yahoo.com

Received Date: Dec 7, 2015; Accepted Date: Jun 29, 2017; Published Date: Jul 02, 2017

Copyright: @ 2017 Mashhour A. This is an open-access article distributed under the terms of the Creative Commons Attribution License, which permits unrestricted use, distribution, and reproduction in any medium, provided the original author and source are credited.

\section{Introduction}

Anal fistula is an important disease in coloproctology. While draining the anal abscess, there is high incidence of complication of anal fistula after surgery $[1,2]$. It is described as small channel, which may be grow between to near the skin of the anus and near to the end of the bowel. Symptomatically, it would be because bleeding and would be painful during passing the stool. Sometimes, it results in recurrent anal abscesses. There is only one treatment or procedure to cure an anal fistula is surgery.

There are different methods for management of anal fistula including fistulotomy, fistulectomy, fibrin glue, rectal advancement flap, anal fistula plug, and ablation with fistuloscope or stem cell injection [3-6]. But, currently sphincter-preserving technique is an ideal technique which is used to cure anal fistula and has been evaluated since long time, currently still in practice. Sphincterpreserving is a good technique for an anal fistula which should be accompanying to decrease recurrence rates and associated with excellent quality of life as compared to conventional techniques. Because, conventional techniques are always risky that associated with continence changes during the procedure. But, still to cure Anal fistula represent a challenge to world [7]. There is need of unconventional and innovative technique which will stands for the upcoming challenges.

The main motto of discussion is to cure anal fistula by removing the primary fistula orifice, remove any secondary fistula orifice, or any related tract without a change in continence.

Fistulotomy is used to treated and remove many of the fistulae which are simple with low recurrence rates [3]. However, complex anal fistula is still very difficult to treat that's represent a challenge now a day.

Fistulectomy nothing but the surgical procedure where it is associated with a fistulous tract is removed completely. This technique is used to remove perianal fistula relating to the individual develop perianal abscess.

Fibrin glue is used to cure anal fistula which is non-surgical treatment option. The glue is inserted into the fistula to cover region, then the orifice is stitched to close. It is a simple, safe and painless procedure, but the results are not worthy.

Rectal Advancement Flap is gold standard to cure complex anal fistula. This technique still has demand in recent procedures and treatment by the colorectal surgeon [8].

Anal fistula plug is the part sub mucosa of small intestine. It is highly absorbable material that is absorbed by the body in 6-8 weeks. This plug is anchored in the fistula tract by a special technique meanwhile, closed internal openings on it. It provides the scaffold over which body's collagen gets deposited and closes the fistula [9].
These all treatment procedures to cure anal fistula, meanwhile, laser and electrode energy techniques are expensive to common people. These techniques are continues systematically evaluated in clinical practice yet [10].

Recently, stem cells therapy has been described to cure disease by using the stem cell. Stem cell has quality that of regenerate tissues and associated with suppressing inflammatory response must elevated and should be better relating on anal fistulae, and studies remain in progress.

Stem cells are nothing but mesenchymal stem cells linked to undifferentiated biological cells that differentiate into specialized cells which is dividing through mitosis to produce more stem cell. Meanwhile, it is associated to treat perianal fistulas. It has the property of immunomodulatory action that will be good to stand for the upcoming challenges and will be benefited for the interdisciplinary research to treat anal fistula [11].

\section{Conclusion}

Treatment of Anal fistula remains in challenging condition to the colorectal surgeon, that condition is associated to fistula location and complexity; despite of availability all advance technology. However, the surgeon becomes familiar with various new techniques to treat an anal fistula with convectional technique as well to remove fistula by surgery. Particularly, the advancement flap is still the gold standard to cure anal fistulae. But there is need of innovative standard, simple technique which will face upcoming challenges. So, current research of immunomodulatory action of the stem cell would be stand for the upcoming challenges.

\section{References}

1. Han KS, Cho HM, Kim DH (2007) Retrospective analysis of a fistula-inano: Focus on an anal-sphincter-preserving procedure. J Korean Soc Coloproctol 23: 403-409.

2. Whiteford MH, Kilkenny J, Hyman N (2005) Practice parameters for the treatment of perianal abscess and fistula-in-ano (revised). Dis Colon Rectum 48: 1337-1342.

3. Lim SW (2009) Surgery in an intersphincteric fistula. J Korean Soc Coloproctol 25: 365-371.

4. Kronborg O (1985) To lay open or excise a fistula-in-ano: A randomized trial. Br J Surg 72: 970.

5. Vasilevsky CA, Gordon PH (1984) The incidence of recurrent abscesses or fistula-in-ano following anorectal suppuration. Dis Colon Rectum 27: 126-130.

6. Van Tets WF, Kuijpers HC (1994) Continence disorders after anal fistulotomy. Dis Colon Rectum 37: 1194-1197.

7. Hwang SH, Bang MJ (2008) Surgery for a complex anal fistula. J Korean Soc Coloproctol 24: 77-82.

8. Song KH (2012) New techniques for treating an anal fistula. Journal of the Korean Society of Coloproctology 28: 7-12. 
Citation: Mashhour A (2017) Anal Fistula and Stem Cell. Human Genet Embryol 7: 140. doi:10.4172/2161-0436.1000140

Page 2 of 2

9. Saba RB, Tizmaghz A, Ajeka S, Karami (2016) M Treating anal fistula with the anal fistula plug: Case series report of 12 patients. Electronic physician 8: 2304.

10. Limura E, Giordano P (2015) Modern management of anal fistula. World Journal of Gastroenterology WJG 21: 12
11. Panes J(2016) Stem cell therapy for perianal fistulas in Crohn's disease. Gastroenterology and hepatology 12: 637. 